\title{
Evaluation of Pasting Properties of Whole Wheat and Whole Green Plantain Flour Blends and Quality Characteristics of Crackers Made from the Blends
}

\author{
U. E. Inyang and V. P. Elijah
}

\begin{abstract}
The demand for food products with functional attributes is on the increase worldwide. The present study was aimed at evaluating the effect of supplementing whole wheat flour with $0,10,20,30,40$ and $50 \%$ whole green plantain flour on pasting properties of the flour blends, proximate composition, minerals and sensory characteristics of crackers made from the blends. The $100 \%$ whole wheat flour served as the control sample. The result showed that the peak viscosity (PV), trough viscosity (TV), breakdown viscosity (BDV), final viscosity (FV) and setback viscosity (SBV) were significantly affected by the level of plantain flour substitution. The $20 \%$ plantain flour substitution level recorded the minimum PV (264.00RVU), TV (248.00RVU), FV (531.00RVU) and SBV (263.00RVU) while the 50\% plantain flour substituted blend recorded the highest PV (362.00RVU), TV (328.00RVU) and FV (603.00RVU). The control sample recorded the highest SBV (312.00RVU) and least BDV (3.00RVU). The peak times for all the blended samples were the same $(7 \mathrm{~min})$ while the time for the control sample was $5 \mathrm{~min}$. There was insignificant difference $(P>0.05)$ in the pasting temperature which ranged from $91.30-92.800 \mathrm{C}$. The crude protein, fat and calcium contents progressively decreased while the ash, crude fibre, carbohydrate, $\mathrm{K}, \mathrm{Mg}, \mathrm{Fe}$ and $\mathrm{Zn}$ contents in the prepared crackers progressively increased with increase in the proportion of plantain flour substitution. Cracker prepared from the blend of $80 \%$ whole wheat and $20 \%$ whole green plantain flours was the most preferred by the sensory evaluation panellists in terms of taste, texture and overall acceptability. It is evident from the study that acceptable crackers of enhanced nutritive value could be produced from blend of $80 \%$ whole wheat and $20 \%$ whole green plantain flours. The use of flour from unpeeled plantain as ingredient in cracker production would eliminate waste generation and its associated environmental problems.
\end{abstract}

Index terms - Crackers quality attributes, pasting properties of flour blends, whole green plantain flour, whole wheat flour.

\section{INTRODUCTION}

Crackers are ready-to-eat, cheap and convenient food products with attractive appearance and long shelf life that are consumed among all types of age group globally [1]. Wheat flour is the main ingredient in cracker production. Unfortunately, the climatic conditions in tropical countries including Nigeria do not promote wheat cultivation. Consequently, researchers have been evaluating the possibility of using flours obtained from locally grown crops such as maize, cassava, rice and African yam beans among

Published on September 17, 2020

U. E. Inyang, University of Uyo, Nigeria.

(e-mail: inyang.ufot@yahoo.com)

V. P. Elijah, University of Uyo, Nigeria. other crops to partially or wholly replace wheat flour for cracker production [2]-[4]. Apart from reducing huge amount of money spent on wheat importation, substitution of non-wheat flour for wheat flour will reduce the gluten content of the product as its consumption usually triggers celiac disease in genetically predisposed individuals. As a popular snack food, cracker can be modified as a functional food through incorporation of various nutritionally and healthy promoting rich ingredients for product diversification, as well as nutritional and health improvement [1].

Crackers made from refined wheat flour lack those components of grain that are intended to be preventive of health such as dietary fibre and phytochemicals that are lost during refining process [5]. Novel functional snack foods including crackers with potential health benefits are in high demand by health conscious consumers. Whole grain wheat flour contains substantially more fibre, vitamins, minerals, antioxidants and other nutrients that are of health benefits to the body than regular wheat flour, since these compounds are concentrated in the outer portion of the grain (bran) [6]. It has been reported that dietary bran-rich food can reduce the risk of hypercholesterolemia, hypertension, breast cancer and type 2-diabetes [7].

Plantain (Musa paradisiaca) is a major starchy food in Nigeria and over 2.1 million metric tons are produced annually, which contributes substantially to the nutritional needs of the rural populace [8]. Plantain is rich in carbohydrate, minerals, vitamins, dietary fibre and resistant starch (RS) [9]. As a climacteric fruit, it is usually harvested at mature green stage to reduce postharvest losses. The unripe fruits are usually peeled and the pulp processed into flour while the peels which constitute about $40 \%$ of the total weight of the fruit [8], [10], are thrown away as waste that contributes to environmental pollution or occasionally used as animal feed. Analysis of unripe plantain peels showed that the peels are rich in antioxidant dietary fibre, minerals and vitamins [8], [9]. Adamu et al. [11] reported that unripe plantain peel had higher $\mathrm{Ca}, \mathrm{Mg}, \mathrm{Mn}$ and $\mathrm{Fe}$ than the pulp and recommended that the peel should be ground into flour and use to fortify plantain pulp flour to increase the nutritional value. Garcia-Valle et al. [12] reported that the resistant starch content in whole plantain flour (4.8-5.8\%) was higher than dietary fibre associated starch in conventional food items such as whole wheat bread (1.7$2.8 \%$ ). Plantain peels also contain substantial levels of bioactive compounds including flavonoids, alkaloids, tannins, phlobatannins and terpenoids [13]. The presence of these compounds is a strong indication that the peels possess 
valuable medicinal properties which are yet to be explored. Based on the above documented information on mature green plantain, the use of both the peel and the pulp as functional food ingredient in a variety of food products including biscuits, cakes and cookies have been proposed [8], [9], [14]. The present study was aimed at evaluating the effect of substituting whole wheat flour with different levels of whole green plantain flour on the pasting properties of the flour blends, nutrient composition and sensory attributes of crackers made from the blends. Production of flour from whole green plantain will increase the yield, prevent waste generation and maximize the use of nutrients and health promoting constituents upon consumption.

\section{MATERIALS AND METHODS}

\section{A. Materials Procurement}

Wheat grains (Triticum aestivum), mature green plantain, sugar, shortening, salt and baking powder were purchased from Akpan Andem market in Uyo, Akwa Ibom state, Nigeria.

\section{B. Preparation of Whole Wheat Flour}

The wheat grains were cleaned from dirt by sorting out contaminants such as sticks, leaves and sand, washed in clean water and dried for $6 \mathrm{hr}$ at $60^{\circ} \mathrm{C}$ in a conventional air oven (model pp, 22 us, Genlab, England). The grains were milled into flour using hammer mill and packaged in air tight plastic container for subsequent use.

\section{Preparation of Whole Green Plantain Flour}

Whole green plantain flour was prepared following the method described by Inyang et al. [15]. The plantain fruits were individually plucked from the plantain hands, washed in tap water, drained, the apex and stalk were cut off and discarded. The unpeeled fruits were individually cut into halves, steam blanched for 10 minutes to inactivate enzymes, drained, cooled, sliced to about $5 \mathrm{~mm}$ thickness using a sharp stainless steel knife and dried in an oven (Model PP, $22 \mathrm{US}$, Genlab, England) at $60{ }^{\circ} \mathrm{C}$ to constant weight. The dried chips were milled with hammer mill into flour and packaged in air tight plastic container for subsequent use.

\section{Formulation of Whole Wheat - Whole Green Plantain Flour Blends}

The formulation of blends utilized for the study were made by blending whole wheat flour with whole green plantain flour in the ratios of 100:00, 90:10, 80:20, 70:30, 60:40 and 50:50 (whole wheat flour: whole green plantain flour). The $100 \%$ whole wheat flour served as control sample.

\section{E. Ingredients Formulation and Cracker Production}

The ingredients used for cracker production comprised of flour $(65.02 \%)$, sugar $(5.20 \%)$, shortening $(8.45 \%)$, salt $(0.52 \%)$, baking powder $(1.63 \%)$ and water $(19.18 \%)$. All ingredients were scaled on the basis of 400 gram flour weight. Crackers were produced using the method described by Khalaf et al. [16] with a slight modification. Butter, sugar, salt and water were mixed for 1 minute in a dough mixer using the flat beater, then scraped down, and continued to mix at high speed for 3 minutes. Flour and baking powder were gradually added to the mixture and mixed at low speed for 3 minutes. The resulted dough was left to rest for 5 minutes and then sheeted to a thickness of $3 \mathrm{~mm}$, cut with a circular shape cutter and baked in an electric oven at $170{ }^{\circ} \mathrm{C}$ for 15 minutes. After baking, crackers were allowed to cool at room temperature $\left(27^{\circ} \mathrm{C}\right)$ for 1 hour, packaged in high density polyethylene bags, labeled and used for various determinations.

\section{F. Determination of Pasting Properties of the Flour Samples}

Pasting properties of the flour samples were determined using a Rapid Visco Analyzer 3C (RVA, Model 3C, Newport Scientific PTY Ltd, Sydney, Australia). Three grams $(3 \mathrm{~g})$ of each sample was weighed into a canister and $25 \mathrm{ml}$ of distilled water was dispensed into the canister containing the sample and mixed thoroughly to form slurry. The canister with the slurry was fitted into the RVA as recommended. The slurry was heated from $50{ }^{\circ} \mathrm{C}$ to $95{ }^{\circ} \mathrm{C}$ with a holding time of $2 \mathrm{~min}$ and cooled to $50^{\circ} \mathrm{C}$ with a holding time of $2 \mathrm{~min}$. The rates of heating and cooling were done at a constant rate of $11.25^{\circ} \mathrm{C} / \mathrm{min}$. The peak viscosity (PV), trough viscosity (TV), breakdown viscosity (BDV), final viscosity (FV), setback viscosity (SBV), peak time and pasting temperature were obtained from the pasting profile with the aid of thermocline for windows software connected to a computer generating the data from the RVA unit [17]. The viscosities were expressed in terms of Rapid Visco Units (RVU).

\section{G. Determination of Nutrients Content}

The crude protein, fat, ash and crude fibre contents in the samples were determined following the methods described in AOAC [18]. The carbohydrate was calculated by subtracting the sum of protein, fat, ash and crude fibre from 100 [19]. Energy value was calculated using Atwater factor formula (Protein X 4 + fat X 9 + carbohydrate X 4) [20]. The mineral elements ( $\mathrm{K}, \mathrm{Ca}, \mathrm{Mg}, \mathrm{Fe}$ and $\mathrm{Zn}$ ) were determined using atomic absorption spectrophotometer (UNICAM, Model 939, UK) as described in AOAC [18].

\section{H. Sensory Evaluation of the Crackers}

Sensory evaluation of the prepared crackers was carried out by a panel of 30 semi-trained judges. Sensory parameter assessed were appearance, taste, aroma, texture and overall acceptability on a 9-point hedonic scale ranging from 1 (dislike extremely) to 9 (like extremely) [21]. The samples served were coded with three digit random numbers and presented in identical containers. Between the samples, the panelists were asked to rinse their mouth with water provided to avoid carry over effect.

\section{Statistical Analysis}

Data generated were subjected to One-way Analysis of Variance (ANOVA) using the software statistical package for social sciences (SPSS) version 18 (SPSS, Inc., Chicago, USA). The difference was considered to be significant at $\mathrm{P}=0.05$. Means were separated using Duncan's Multiple Range Test (DMRT). 


\section{RESUlts AND Discussion}

\section{A. Effect of the Treatment on Pasting Properties}

Pasting properties is an important index in determining the cooking and baking qualities of flour and is often used as index of predicting the ability of starch-based food to form a viscous paste or gel when subjected to heat application. These properties affect the texture, stability and digestibility as well as the end use of starch-based food commodities
[22]. The analyzed RVA pasting properties of whole wheat flour supplemented with different levels of whole green plantain flour are presented on Table 1 . The result showed significant differences $(\mathrm{P}<0.05)$ in RVA parameters among the flour blends during heating and cooling possibly because of the differences in composition between whole wheat and whole green plantain flours.

TABLE 1: Pasting Properties Of Whole Wheat Flour Supplemented With Whole Green Plantain Flour

\begin{tabular}{|c|c|c|c|c|c|c|}
\hline \multirow{2}{*}{ Pasting properties } & \multicolumn{6}{|c|}{ Blending ratios (whole wheat flour: whole plantain flour) } \\
\hline & 100:00 & 90:10 & 80:20 & 70:30 & $60: 40$ & 50:50 \\
\hline Peak viscosity (RVU) & $293.00^{\mathrm{d}} \pm 4.01$ & $279.00^{\mathrm{e}} \pm 2.95$ & $264.00^{\mathrm{f}} \pm 5.14$ & $302.00^{c} \pm 3.72$ & $337.00^{\mathrm{b}} \pm 3.18$ & $362.00^{\mathrm{a}} \pm 4.22$ \\
\hline Trough viscosity (RVU) & $290.00^{c} \pm 3.95$ & $269.00^{\mathrm{e}} \pm 5.02$ & $248.00^{\mathrm{f}} \pm 2.68$ & $284.00^{\mathrm{d}} \pm 6.10$ & $309.00^{\mathrm{b}} \pm 4.09$ & $328.00^{\mathrm{a}} \pm 3.75$ \\
\hline Breakdown viscosity (RVU) & $3.00^{\mathrm{f}} \pm 5.11$ & $10.00^{\mathrm{e}} \pm 3.60$ & $16.00^{\mathrm{d}} \pm 4.73$ & $18.00^{\mathrm{c}} \pm 2.53$ & $28.00^{\mathrm{b}} \pm 4.61$ & $34.00^{\mathrm{a}} \pm 1.92$ \\
\hline Final viscosity (RVU) & $602.00^{\mathrm{a}} \pm 4.33$ & $572.00^{c} \pm 1.86$ & $531.00^{\mathrm{d}} \pm 3.05$ & $574.00^{c} \pm 4.30$ & $597.00^{\mathrm{b}} \pm 2.80$ & $603.00^{\mathrm{a}} \pm 4.53$ \\
\hline Setback viscosity (RVU) & $312.00^{\mathrm{a}} \pm 2.90$ & $303.00^{\mathrm{b}} \pm 4.21$ & $263.00^{f} \pm 5.60$ & $290.00^{c} \pm 1.85$ & $288.00^{\mathrm{d}} \pm 3.63$ & $275.00^{\mathrm{e}} \pm 2.85$ \\
\hline Peak time (Min) & $5.67^{\mathrm{b}} \pm 0.11$ & $7.00^{\mathrm{a}} \pm 0.5$ & $7.00^{\mathrm{a}} \pm 0.02$ & $7.00^{\mathrm{a}} \pm 0.10$ & $7.00^{\mathrm{a}} \pm 0.03$ & $7.00^{\mathrm{a}} \pm 0.05$ \\
\hline Pasting temperature $\left({ }^{\circ} \mathrm{C}\right)$ & $92.80^{\mathrm{a}} \pm 0.20$ & $92.10^{\mathrm{a}} \pm 0.10$ & $92.15^{\mathrm{a}} \pm 0.06$ & $91.30^{\mathrm{a}} \pm 0.03$ & $91.30^{\mathrm{a}} \pm 0.00$ & $92.05^{\mathrm{a}} \pm 0.03$ \\
\hline
\end{tabular}

The peak viscosity (PV) is the maximum viscosity developed during or soon after the heating aspect of the test [23]. It is indicative of the viscous load likely to be encountered during mixing and its relation to final product quality [24]. The PV of the flour blends decreased significantly $(\mathrm{P}<0.05)$ from 293.00RVU for the control sample to $264.00 \mathrm{RVU}$ for the $20 \%$ plantain flour substituted sample and then increased progressively to a maximum of 362.00RVU for the $50 \%$ plantain flour substituted sample. The PV value for the $100 \%$ whole wheat flour was within the range $(175-295 \mathrm{RVU})$ reported by Black et al. [25] for wheat flour. Differences observed in the PV of the samples indicate that there were differences in the rate of water absorption and starch granule swelling during heating [26]. The recorded progressive increase in the PV values of plantain flour substituted sample above $20 \%$ could be attributed to increase in starch content with increase in plantain flour substitution. According to Shittu et al. [27], the higher the PV of the sample, the higher the swelling index of starch, while low PV is indicative of higher solubility as a result of starch degradation or dextrinization.

Trough viscosity (TV) otherwise known as holding strength viscosity and final viscosity (FV) followed the same trend as pasting viscosity. Trough viscosity is the point at which the viscosity reaches its minimum during either heating or cooling processes and measures the ability of the paste or gel formed to withstand breakdown during cooling [28]. The $20 \%$ plantain flour substituted sample recorded the least trough viscosity value (248.00RVU) while the $50 \%$ plantain flour substituted sample exhibited the highest value (328.00RVU). The value for the control sample was 290RVU. The TV increased as the percentage inclusion of plantain flour above $20 \%$ increased. This may be due to the swelling capacity of the starch granules in whole green plantain flour [29]. The lower the TV, the more stable is the starch gel [30]. The final viscosity, a parameter commonly used to determine a sample's ability to form a viscous paste or gel on cooling [24], [31], ranged from 531.00RVU for the $20 \%$ plantain flour substituted sample to $603.00 \mathrm{RVU}$ for the $50 \%$ plantain flour substituted sample. The value for the $100 \%$ wheat flour (602.00RVU) was lower than 781RVU reported for whole wheat flour [32] due possibly to varietal differences. The FV increase in plantain flour substituted samples above $20 \%$ could be attributed to higher starch content in plantain flour than in whole wheat flour. This result is in agreement with the report by Chinma et al. [33] that plantain flour had higher FV than wheat flour. According to Tester and Morrison [34], FV depends on starch content, amylose, amylopectin, as well as amylose/ amylopectin ratio.

Breakdown viscosity (BDV) is the difference between the peak viscosity and trough viscosity and measures the tendency of swollen granules to rupture when held at high temperature and continuous shearing [35]. The BDV increased significantly $(\mathrm{P}<0.05)$ with increase in plantain flour substitution ranging from 3.00RVU for the control sample to $34.00 \mathrm{RVU}$ for the $50 \%$ plantain flour substituted sample. High BDV is associated with increased susceptibility of flour to withstand heating and shear stress during cooking [23]. The result shows that the control sample with the least BDV exhibited higher hot paste stability than the plantain flour substituted samples. Setback viscosity (SBV), a parameter that gives an idea about retrogradation tendency of starch in flour samples [29], ranges from 263.00RVU to 312.00RVU with the control sample recording the highest value while the $20 \%$ plantain flour substituted sample had the least value. The reduction in SBV as a result of incorporation of whole green plantain flour indicates reduction in the textural characteristics of the samples since SBV of starch-based food has been correlated with texture of various end products [22]. Unripe plantain flour has been reported to be high in amylose content and this may account for lower value of SBV in flour with plantain flour inclusion than in the control sample [33]. Low SBV is an indication that the starch has low tendency to retrograde or undergo syneresis [36].

Peak time is the time in minutes at which peak viscosity occurred. The peak time was 5 minutes for the control sample while all the plantain flour substituted samples recorded the same peak time (7 minutes). Low peak time is indicative of the sample's ability to cook fast. This implies that the control sample with lower peak time will cook faster than plantain flour substituted samples. Pasting temperature 
is indicative of the minimum temperature required to cook or gelatinize the flour [37], and also indicative of energy cost. The pasting temperatures ranged from $91.30-92.80^{\circ} \mathrm{C}$. There were no significant differences $(\mathrm{P}>0.05)$ in the pasting temperatures among the samples, but the control sample recorded higher pasting temperature than the values recorded for plantain flour substituted samples.

\section{B. Effect of the Treatment on Nutrient Composition}

The effect of partial replacement of whole wheat flour with whole green plantain flour on the nutrient composition of crackers made from the blends is presented on Table 2. The result showed that the crude protein and fat contents progressively decreased from $9.86-6.97 \%$ and $11.51-7.75 \%$ respectively with increase in the level of whole plantain flour substitution. Wheat flour has been reported to contain $10.54 \%$ protein and $5.40 \%$ fat [38] while whole green plantain flour contains $3.65-5.45 \%$ protein and $0.58-1.65 \%$ fat [39]. The decrease in protein and fat contents in the crackers with increase in plantain flour substitution could therefore be attributed to lower protein and fat contents in whole plantain flour than in whole wheat flour. The protein and fat contents recorded for $100 \%$ whole wheat cracker (control sample) were lower than $11.88 \%$ and $15.39 \%$ respectively reported for whole wheat cracker [40]. The differences could be due to variety of wheat grain and ingredients used in cracker formulation. On the contrary, the ash, crude fibre and carbohydrate contents in the crackers increased progressively from $2.04-2.93 \%, 2.15-3.26 \%$ and $74.44-79.59 \%$ respectively with increase in plantain flour substitution, due possibly to higher contents of minerals, crude fibre and carbohydrate in plantain flour than in wheat flour. In full agreement with the result of this study, Chinma et al. [33] reported that cookies made from $100 \%$ wheat flour had higher protein and fat contents but lower ash, crude fibre and carbohydrate contents than cookies made from unripe plantain flour. Badejo et al. [30] had earlier reported that whole green plantain flour is a rich source of crude fibre, carbohydrate and mineral elements. The high crude fibre content in whole plantain flour substituted crackers is indicative of health promoting potentials upon consumption. Dietary fibre has no nutritional value but it is beneficial to health. Adequate consumption of dietary fibre is associated with reduced risk of several chronic diseases, such as type 2 diabetes, cardiovascular disease (CVD), colorectal cancer, obesity, high blood pressure and lowered serum cholesterol [41]. The relatively low fat content and high fibre content of whole plantain flour substituted crackers suggest that the product could be helpful to diabetic and hypertensive individuals. The caloric value of the samples decreased from $440.79-411.49 \mathrm{kcal} / 100 \mathrm{~g}$ with increase in plantain flour substitution. This could be due to decrease in fat content with increase in plantain flour substitution since the contribution of fat to energy value is $9 \mathrm{kcal} / \mathrm{g}$ as against $4 \mathrm{kcal} / \mathrm{g}$ by protein and carbohydrate [20].

The ash content of a food material is an indication of the mineral level in such food. Mineral nutrients are important for the functioning of numerous metabolic processes in the body and their deficiency in food can cause different types of disorders. The calcium content in the crackers decreased from $51.08-40.24 \mathrm{mg} / 100 \mathrm{~g}$ while the potassium, magnesium, iron and zinc contents increased from 236.81$342.32 \mathrm{mg} / 100 \mathrm{~g}, 118.52-175.80 \mathrm{mg} / 100 \mathrm{~g}, 3.26-4.10 \mathrm{mg}$ / $100 \mathrm{~g}$ and $1.98-2.75 \mathrm{mg} / 100 \mathrm{~g}$ respectively with increase in whole plantain flour substitution (Table 2). The result indicates that the $\mathrm{Ca}$ content was higher while the $\mathrm{K}, \mathrm{Mg}, \mathrm{Fe}$ and $\mathrm{Zn}$ contents were lower in whole wheat flour than in whole green plantain flour. The plantain peel that was part of the whole plantain flour would have contributed significantly to the mineral content in the prepared flour. Various authors [8], [11], [13], [30], have reported that plantain peel is a rich source of minerals and advocated that it should be incorporated in the formulation and development of functional foods. Adequate dietary calcium is required throughout life to prevent low bone mineral density, decrease risk of fragility and osteoporosis at a mature age [42]. Potassium is the building block of body tissues, and hence essential for the growth of infants [43]. Magnesium is a co-factor in more than 300 enzyme systems that regulate diverse biochemical reactions in the body including protein synthesis, muscle and nerve function, blood glucose control and blood pressure regulation [44]. Iron is vital for the production of hemoglobin, formation of red blood cells and oxygenation of red blood cells [45]. It is essential to have adequate iron in the diet of infants and young children to combat iron deficiency anemia which is of public health concern worldwide. Zinc is essential for the synthesis of DNA and RNA, proteins, insulin and sperm, essential for proper functioning of immunity system and for activation of over 80 enzymes [42]. It is evident from the result of this study that crackers prepared from blends of whole wheat and whole green plantain flours could become good source for providing the aforementioned mineral elements and helpful in overcoming their nutritional deficiencies.

TABLE 2:NuTRIENT COMPOSITION OF CRACKERS MADE From BLENDS OF WHOLE WhEAT AND WHOLE GREEN PLANTAIN FLOUR (DRY MATTER BASIS)

\begin{tabular}{ccccccc}
\hline \multirow{2}{*}{ Parameters } & \multicolumn{5}{c}{ Blending ratios (whole wheat flour: whole plantain flour) } \\
\cline { 2 - 6 } & $\mathbf{1 0 0 : 0 0}$ & $\mathbf{9 0 : 1 0}$ & $\mathbf{8 0 : 2 0}$ & $\mathbf{7 0 : 3 0}$ & $\mathbf{6 0 : 4 0}$ \\
\hline Protein (\%) & $9.86^{\mathrm{a}} \pm 0.04$ & $9.28^{\mathrm{b}} \pm 0.06$ & $8.90^{\mathrm{c}} \pm 0.10$ & $8.41^{\mathrm{d}} \pm 0.08$ & $7.95^{\mathrm{e}} \pm 0.05$ & $6.97^{\mathrm{f}} \pm 0.02$ \\
Fat (\%) & $11.51^{\mathrm{a}} \pm 0.02$ & $10.66^{\mathrm{b}} \pm 0.00$ & $9.78^{\mathrm{c}} \pm 0.04$ & $8.96^{\mathrm{d}} \pm 0.03$ & $8.10^{\mathrm{d}} \pm 0.08$ & $7.25^{\mathrm{f}} \pm 0.05$ \\
Ash (\%) & $2.04^{\mathrm{c}} \pm 0.05$ & $2.35^{\mathrm{b}} \pm 0.11$ & $2.47^{\mathrm{b}} \pm 0.08$ & $2.55^{\mathrm{b}} \pm 0.10$ & $2.71^{\mathrm{a}} \pm 0.03$ & $2.93^{\mathrm{a}} \pm 0.10$ \\
Crude fibre (\%) & $2.15^{\mathrm{d}} \pm 0.13$ & $2.28^{\mathrm{d}} \pm 0.09$ & $2.40^{\mathrm{c}} \pm 0.10$ & $2.71^{\mathrm{c}} \pm 0.12$ & $3.01^{\mathrm{b}} \pm 0.09$ & $3.26^{\mathrm{a}} \pm 0.14$ \\
Carbohydrate (\%) & $74.44^{\mathrm{c}} \pm 0.10$ & $75.43^{\mathrm{c}} \pm 0.05$ & $76.45^{\mathrm{b}} \pm 0.02$ & $77.37^{\mathrm{b}} \pm 0.06$ & $78.23^{\mathrm{a}} \pm 0.04$ & $79.59^{\mathrm{a}} \pm 0.06$ \\
Caloric value (kcal/100g) & $440.79^{\mathrm{a}} \pm 0.06$ & $434.78^{\mathrm{b}} \pm 0.08$ & $429.42^{\mathrm{b}} \pm 0.03$ & $423.76^{\mathrm{b}} \pm 0.04$ & $417.62^{\mathrm{c}} \pm 0.06$ & $411.49^{\mathrm{c}} \pm 0.05$ \\
K (mg/100g) & $236.81^{\mathrm{f}} \pm 0.14$ & $257.20^{\mathrm{e}} \pm 0.31$ & $276.71^{\mathrm{d}} \pm 0.09$ & $294.83^{\mathrm{c}} \pm 0.22$ & $322.65^{\mathrm{b}} \pm 0.18$ & $342.32^{\mathrm{a}} \pm 0.21$ \\
Ca (mg/100g) & $51.08^{\mathrm{a}} \pm 0.20$ & $49.47^{\mathrm{a}} \pm 0.15$ & $46.86^{\mathrm{b}} \pm 0.20$ & $44.65^{\mathrm{b}} \pm 0.13$ & $41.98^{\mathrm{c}} \pm 0.15$ & $40.24^{\mathrm{c}} \pm 0.14$ \\
Mg (mg/100g) & $118.52^{\mathrm{f}} \pm 0.11$ & $130.25^{\mathrm{c}} \pm 0.17$ & $141.19^{\mathrm{d}} \pm 0.31$ & $154.07^{\mathrm{f}} \pm 0.10$ & $166.34^{\mathrm{b}} \pm 0.09$ & $175.80^{\mathrm{a}} \pm 0.23$ \\
Fe (mg/100g) & $3.26^{\mathrm{c}} \pm 0.09$ & $3.42^{\mathrm{b}} \pm 0.12$ & $3.60^{\mathrm{b}} \pm 0.08$ & $3.75^{\mathrm{b}} \pm 0.16$ & $3.93^{\mathrm{a}} \pm 0.24$ & $4.10^{\mathrm{a}} \pm 0.12$ \\
Zn (mg/100g) & $1.98^{\mathrm{c}} \pm 0.23$ & $2.14^{\mathrm{b}} \pm 0.14$ & $2.31^{\mathrm{b}} \pm 0.11$ & $2.47^{\mathrm{a}} \pm 0.09$ & $2.59^{\mathrm{a}} \pm 0.18$ & $2.75^{\mathrm{a}} \pm 0.06$ \\
\hline
\end{tabular}




\section{Effect of the Treatment on Sensory Attributes of the Crackers}

Sensory quality is the ultimate criterion for the acceptance or rejection of newly developed food product. This makes sensory evaluation an important component of new food product formulation and development. Mean sensory evaluation scores for various sensory characteristics (appearance, taste, texture, aroma and overall acceptability) of crackers made from composite of whole wheat and whole green plantain flours are presented in Table 3. The result revealed that the scores by the judges for the various attributes varied among the samples. The mean scores for appearance and aroma of plantain flour substituted crackers up to $20 \%$ did not differ significantly from those of the control sample but were significantly $(\mathrm{P}<0.05)$ higher than those with plantain flour inclusion level above $20 \%$. Crackers produced from $20 \%$ plantain flour substitution had the highest mean scores of 7.06 and 6.08 for taste and texture respectively while the $50 \%$ plantain flour substituted crackers had the least scores of 4.70 and 4.81 respectively. There were no significant differences $(P>0.05)$ between the taste and texture of the control sample and cracker made from $10 \%$ plantain flour substitution but their scores were significantly $(\mathrm{p}<0.05)$ higher than those for crackers from plantain flour substitution level above $20 \%$. Flavour (taste and aroma) of a food ultimately determines its acceptance or rejection even though its appearance induces the first response. Texture of the crackers determines their chewing ability and therefore plays an important role in justifying their overall acceptability. For the overall acceptability, the $20 \%$ plantain flour substituted cracker had the highest mean score of 7.10 while the least score of 5.30 was for the $50 \%$ plantain flour substituted cracker. The results showed that cracker prepared from the blend of $80 \%$ whole wheat flour and $20 \%$ whole green plantain flour was preferred more than the $100 \%$ whole wheat cracker and crackers made from the other flour blends.

TABLE 3: MeAn Sensory Values For Crackers Produced From Blends Of Whole WheAt And WhOLE GReEn Plantain Flours

\begin{tabular}{lcccccc}
\hline \multicolumn{1}{c}{ Sensory attributes } & \multicolumn{5}{c}{ Blending ratios (whole wheat flour: whole plantain flour) } \\
\cline { 2 - 6 } & $\mathbf{1 0 0 : 0 0}$ & $\mathbf{9 0 : 1 0}$ & $\mathbf{8 0 : 2 0}$ & $\mathbf{7 0 : 3 0}$ & $\mathbf{6 0 : 4 0}$ \\
\hline Appearance & $6.78^{\mathrm{a}} \pm 0.10$ & $6.90^{\mathrm{a}} \pm 0.14$ & $6.81^{\mathrm{a}} \pm 0.08$ & $5.72^{\mathrm{b}} \pm 0.06$ & $5.50^{\mathrm{b}} \pm 0.20$ & $5.49^{\mathrm{b}} \pm 0.11$ \\
Taste & $6.39^{\mathrm{b}} \pm 0.06$ & $6.40^{\mathrm{b}} \pm 0.08$ & $7.06^{\mathrm{a}} \pm 0.15$ & $5.84^{\mathrm{c}} \pm 0.10$ & $5.42^{\mathrm{c}} \pm 0.08$ & $4.70^{\mathrm{c}} \pm 0.05$ \\
Texture & $6.30^{\mathrm{b}} \pm 0.20$ & $6.39^{\mathrm{b}} \pm 0.10$ & $6.80^{\mathrm{a}} \pm 0.21$ & $5.73^{\mathrm{c}} \pm 0.09$ & $5.30^{\mathrm{c}} \pm 0.11$ & $4.81^{\mathrm{d}} \pm 0.14$ \\
Aroma & $6.15^{\mathrm{a}} \pm 0.11$ & $6.24^{\mathrm{a}} \pm 0.13$ & $6.22^{\mathrm{a}} \pm 0.06$ & $5.61^{\mathrm{b}} \pm 0.13$ & $5.50^{\mathrm{b}} \pm 0.15$ & $5.42^{\mathrm{b}} \pm 0.09$ \\
Overall acceptability & $6.80^{\mathrm{b}} \pm 0.09$ & $6.82^{\mathrm{b}} \pm 0.09$ & $7.10^{\mathrm{a}} \pm 0.11$ & $6.52^{\mathrm{c}} \pm 0.10$ & $5.71^{\mathrm{d}} \pm 0.06$ & $5.30^{\mathrm{e}} \pm 0.0139$ \\
\hline
\end{tabular}

\section{CONCLUSION}

The study has shown that the pasting behaviour of whole wheat flour supplemented with whole green plantain flour depended on the supplementation ratios of the whole green plantain flour. The protein, fat and calcium contents in the prepared crackers decreased while ash, crude fibre, carbohydrate, $\mathrm{K}, \mathrm{Mg}, \mathrm{Fe}$ and $\mathrm{Zn}$ contents increased with increase in green plantain flour supplementation. Of all the crackers produced from the various blends, the $80 \%$ whole wheat and $20 \%$ whole green plantain cracker was rated as the most preferred by the sensory evaluation panelists. Partial replacement of whole wheat flour with whole green plantain flour for cracker production will reduce the demand for imported wheat; eliminate waste generation as peels and the environmental problems associated with the disposal of such peels. The produced cracker is expected to add variety to the cracker grocery stores and its potential consumers stand to benefit from the nutrients, bioactive compounds and dietary fibre present in plantain peel that is usually thrown away as waste.

\section{REFERENCES}

[1] H. M. T. Herath, K. M. D. T. Rupasinghe, D. Priyanoni and M. S. W De Silva. Formulation and Physicochemical Properties of dietary fibre enhanced low glycemic multi-grain cracker for adults using locally available cereals and legumes. Research Journal of Chemical Sciences, vol. 8, no. 8, pp 6-15, 2018.

[2] T. C. E. Mosha, M. A. Sadick and H. S. Laswai. Development and evaluation of organoleptic quality and acceptability of cassava-based composite cracker for supplementing primary school children. Tanzanian Journal of Agricultural Science, vol. 10, no. 1, Pp 8-21, 2010.

[3] K. Venkatachalam and M. Nagarajan. Physicochemical and sensory properties of savory cracker incorporating green gram flour to partially or wholly replace wheat flour. Italian Journal of Food Science, vol. 29, pp 599-612, 2017.

[4] E. C. Okoye, J. C. Ani, G. R. Ugwuanyi and O. C. Oyeoku. Quality assessment of crackers from the flour blends of wheat, maize African yam bean seed and cassava cortex. Journal of Clinical Nutrition and Food Chemistry. 1:002 JCNFC - 002. 000002, 2020.

[5] A. Fardet. New hypothesis for the health preventive mechanism of whole grain cereals: What is beyond fiber? Nutrition Research and Revision, vol. 23, no. 01, pp 65-134, 2010.

[6] G. L. Weaver. A miller's perspective on the impact of health claims. Nutrition Today, vol. 36, pp 115-118, 2001

[7] F. N. Ndlala, O. O. Onipe, T. M. Mokhele, T. A. Anyasi and A. I. O. Jideani. Effect of wheat bran incorporation on the physical and sensory properties of a South African cereal fried dough. Foods, vol. 8, no. 11, pp 559, http://doi.10.3390/foods 8110559, 2019.

[8] A. O. Akinsanmi, G. Oboh, A. J. Ayodele, A. A. Stephen. Assessment of the nutritional, antinutritional and antioxidant capacity of unripe, ripe and over plantain (Musa paradisiaca) peels. International Journal of Advanced Research, vol. 3, no. 2, pp 63-72, 2015.

[9] K. B. Arun, F. Persia, P. S. Aswathy, J. Chandran, M. S. Sajeev, P. Jayamurthy and P. Nisha. Plantain peel - a potential source of antioxidant dietary fibre for developing functional cookies. Journal of Food Science and Technology, vol. 52, no. 10, pp 6355-6364, 2015.

[10] R. Gilver and S. Liliana. Effect of plantain (Musa paradisiaca L. CV. Dominoto harton) peel flour as binder in Frank further type sausage. Acta Agronomy, vol. 66, no. 3, pp 305-310, 2017.

[11] A. S. Adamu, I. O. Ojo and J. C. Oyetunde. Evaluation of nutritional values in ripe, unripe, boiled and roasted plantain (Musa paradisiaca) pulp and peel. European Journal of Basic and Applied Science, vol. 4 no. 1, pp 9-12, 2017

[12] D. E. Garcia-Valle, L. A. Bello-Perez, P. C. Flores-Silva, E. AgamaAcevedo and J. Tovar. Extruded unripe plantain flour as an indigestible carbohydrate - rich ingredient. Frontiers in Nutrition, vol. 6, no. 2, http://doi.10.3389/fnut.2019. 00002, 2019.

[13] O. M. Ighodaro. Evaluation study on Nigerian species of Musa paradisiaca peels: Phytochemical screening, proximate analysis, mineral composition and anti-microbial activities. Researcher, vol. 4 no. 8, pp 17-20, 2012.

[14] E. Agama-Acevedo, J. A. Sanudo-Barajas, R. Valez De La Rocha, G A. Gonzalez-Aguilar, and L. A. Bello-Perez. Potential of plantain peel flour (Musa paradisiaca L.) as a source of dietary fibre and antioxidant compounds. CYTA - Journal of Food, vol. 14, no. 1, pp 117-123, 2016. 
[15] U. E. Inyang, S. E. Nkop and E. B. Umoh. Effect of the stage of ripening on the nutrients, antinutrients and functional properties of flours made from whole plantain fruit. Current Journal of Applied Science and Technology, vol. 23, no. 1, pp 1-9, 2017.

[16] H. H. A. Khalaf, R. M. A. Elsadany, A. I. Galah, G. A. I. Ghazal, M. F. M. Afifi and N. A. M. Fayed. Development and evaluation of nutritional value of sesame cracker for supplementing primary school children. Middle East Journal of Applied Science, vol. 9, no. 2, pp 494-501, 2019.

[17] Newport Scientific. Applications manual for the Rapid Visco Analyzer using thermocline for windows. Newport Scientific Pty Ltd, Australia, 1998, pp 2-26.

[18] AOAC. Official methods of analysis (18 $18^{\text {th }}$ edn.). Association of Official Analytical Chemists, Washington DC, USA, 2010.

[19] G. I. Onwuka. Food analysis and instrumentation, Naphthali prints, Lagos, 2005, pp 89.

[20] D. R. Osborne and P. Voogt. The analysis of nutrients in foods. Academic press, New York, 1978, p 237.

[21] M. O. Iwe. Current trends in sensory evaluation of foods. Rojoint Communication Services Ltd, Enugu, Nigeria, 2007, pp 137-138.

[22] A. A. Adebowale, L. O. Sanni and S. O. Awonorin. Effect of texture modifiers on the physicochemical and sensory properties of dried fufu. Food Science International Journal, vol. 11, pp 373-382, 2005

[23] A. A. Adebowale, L. O. Sanni and F. O. Ladapo. Chemical, functional and sensory properties of instant yam-breadfruit. Nigerian Food Journal, vol. 26, pp 2-12, 2008.

[24] B. Maziya-Dixon, A. G. Dixon, A. A. Adebowale. Targeting different uses of cassava geotropic variation for cyanogenic potential and pasting properties. International Food Science and Technology, vol. 42, pp 969-976, 2007.

[25] C. K. Black, J. F. Panozzo, C. L. Wright and D. C. Lim. Survey of white salted noodle quality characteristics in wheat landraces. Cereal Chemistry, vol. 77, no. 4, pp 468-472, 2000.

[26] S. Ragaee and E. S. M. Abdel-Aal. Pasting properties of starch and protein in selected cereals and quality of their food products. Food Chemistry, vol. 95, no. 1, pp 9-18, 2006.

[27] T. A. Shittu, O. O. Lasekan, L. O. Sanni and M. O. Oladosu. The effect of drying methods on the functional and sensory characteristics of pupuru-a fermented cassava product. ASSET Series A, vol. 1, no. 2, pp 9-16, 2001.

[28] H. N. Ayo-Omogie and R. Ogunsakin. Assessment of chemical, rheological and sensory properties of fermented maize - cardaba banana complementary food. Food and Nutrition Science, vol. 4, pp 844-850, 2013.

[29] E. R. Ohizua, A. A. Adeola, M. A. Idowu, O. P. Sobukola, T. A. Afolabi, R. O. Ishola, S. O. Ayansina, T. O. Oyekale and A. Falomo. Nutrient composition, functional, and pasting properties of unripe cooking banana, pigeon pea, and sweet potato flour blends. Food Science and Nutrition, vol. 5, no. 3, pp 750-762, 2017.

[30] A. A. Badejo, A. P. Osunlakin, A. Famakinwa, A. O. Idowu and T. N. Fagbemi. Analysis of dietary fibre contents, antioxidants composition, functional and pasting properties of plantain and moringa composite flour blends. Cogent Food and Agriculture, vol. 3, no. 1 , http://doi.org/10.1080/23311932.2017.1278871, 2017.

[31] M. A. Ajatta, S. A. Akinola and O. F. Osundahunsi. Proximate, functional and pasting properties of composite flours made from wheat, breadfruit and cassava starch. Applied Tropical Agriculture, vol. 21, no. 3, pp 158-165, 2016.

[32] O. A. Olaoye, I. G. Lawrence and A. K. Animasahun. Functional and pasting properties of flour blends from wheat and bambara nut and their bread making potential. Nigerian Food Journal, vol. 36, no. 1, pp 1-11, 2018

[33] C. E. Chinma, B. D. Igbabul and O. O. Omotayo. Quality characteristics of cookies prepared from unripe plantain and defatted sesame flour blends. American Journal of Food Technology, vol. 7, pp 398-408, 2012.

[34] R. F. Tester and W. R. Morrison. Swelling and amylosization of cereal starches. I Effects of amylopectin, amylose and lipid. Cereal Chemistry, vol. 67, pp 551-557, 1990.

[35] J. Patindola, Y. Wanga and J. Jane. Structure - functionality changes in starch following rough rice storage. Starch/Stārke, vol. 57, pp 197. 207, 2005.

[36] I. Choi, C. Kang, y. Cheong, J. Hyun and K. Kim. Substituting normal and waxy-type whole wheat flour on dough and baking. Preventive Nutrition and Food Science, vol. 17, no. 3, pp 197-202, 2012.

[37] M. Kaur and N. Singh. Studies on functional, thermal and pasting properties of flours from different chickpea (Cicer arietinum L.) cultivars. Food Chemistry, Vol. 91, pp 403-411, 2005.
[38] B. I. Offia-Olua. Chemical, functional and pasting properties of wheat (Triticum spp) - walnut (Juglans regia) flour. Food and Nutrition Science, vol. 5, pp 1591-1604, 2014

[39] T. A. Adeniji, L. O. Sanni, I. S. Barimalaa and A. D. Hart. Nutritional and anti-nutritional composition of flour made from plantain and banana hybrid pulp and peel mixture. Nigerian Food Journal, vol. 25 no. 2, pp 68-76, 2007.

[40] A. T. Idowu, S. Benjakul, s. Sinthusamran, J. Pongsetkul, T. SaeLeaw and P. Sookchoo. Whole wheat cracker fortified with biocalcium and protein hydrolysate powders from salmon frame: Characteristics and nutritional value. Food Quality and Safety, vol. 3 , no. 3, pp 191-199, 2019.

[41] Academy of Nutrition and Dietetics. Position of the academy of nutrition and dietetics: health implications of dietary fibre. Journal of the Academy of Nutrition and Dietetics, vol. 115, pp 1861-1870, 2015

[42] T. T. Lilly, J. K. Immaculata and P. Jamila. Macro and micronutrients of selected marine fishes in Tuticorin, South East Coast of India International Food Research Journal, vol. 24, no.1, pp 191-201, 2017.

[43] M. H. Golden. Proposed recommended nutrients densities for moderately malnourished children. Food and Nutrition Bulletin, vol 30, no. 2, pp 267-342, 2009.

[44] R. M. Touyz. Role of magnesium in the pathogenesis of hypertension. Molccular Aspects of Medicine, vol. 24, no.1-3, pp 107-136, 2003

[45] A. R. Gbadegesin, S. O. Gbadamosi and T. V. Odunlode. Physicochemical and sensory properties of pineapple flavoured roselle powders. Cogent Food and Agriculture, vol. 3 http://doi.org/10.1080/23311932.2017. 1292833, 2017. 